\title{
DOES DEPTH AND SEDIMENTATION IN'TERACT WITH SEA LRCHINS TO AFFECT ALGAL ASSEMBLAGE PATTERNS ON EASTERN ATLANTIC REEFS?
}

\author{
LEONOR ORTEGA-BORGES, ${ }^{1}$ FERNANDO TUYA ${ }^{2,3_{*}^{*}}$ AND RICARDO J. HAROUN ${ }^{1}$ \\ 'BIOGES. Camptes de Tafira sin. University of Las Palmas de G.C., 35017 Las Palmas de G.C., Canary' \\ Islands. Spain: ' CHMAR. Rua dos Bragas 289, 450-123 Porto, Porthgal, " Centre for Marine Ecosystem \\ Researd, Edith Cowan University. Joondatup, 6027 Western Australia, Australia
}

\begin{abstract}
A range of liators may aftect the composition and abundiance of macroalgate on subtidial recky reefs. We

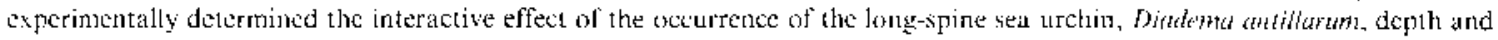
sedimentation levels on macroalęal assemblage structure on ealstern Atlantic rocky reets.s. Specilically, we manipulated sea urchin densitics (removal of all individuals vs. unlouched controls it natural densitjesj on rocky reefs devoid of erect vegetation. and predicted (1) that removil of sea urchins would differenlly aflect malcroialgal assemblage structure between deep (16 $18 \mathrm{~m}$ ) ancl shallow ( $8.9 \mathrm{~m}$ ) reel strallat. and that (2) the effect of sea urchirs removal on nacroalgae would be altered under difterent seenarios of sedimentation (ambient vs. enhanced). Experimental circular plots ( $2 \mathrm{~m}$ in thiameter) were sel up at 3 locations at Gran Canariat (Canarian Archipelago), and were maintained and monitored cvery 4 wh for $1 \mathrm{y}$. At the end of the experimental period. the structure of the algat assemhlages differed between urchin treattments and depth strata. with a latger cover of turl and bushlike algate where urchins were removed and at the shallow reef stratum. More important, differences in algal assemblage strueture between urchin treatments were irrespective of sedimentation levels, but shifted from the shallow to the deep stratum. This interactive effect was, in turn, observed for bushlike algac, as a result of a larger matenitude of response (j.e. larger cover) in the shallow strat un relative to the deep siratum, but was not deleted for either turf or crustose coralline allade. These rewul ts highlight the importance of some physical conditions (hers. diterences in depth) to interact with biotic processes (here, urchin abundance) to ereste patterns in the organization of subtidil and bentlic assernblitges.
\end{abstract}

KEY WORDS: macroalgae. benthic assemblages. assembjage structure, seat urchins. sedinentation, depth stratia

\section{INTRODLICTION}

Subtidal temperate habitats are haterogeneous. A range of factors may facilitate or disturb the presence and abundance of subtidal macroalgate living on hard hottoms, and thereby affect their composition and assemblatge structure (Lüning 1990). For example, light, sedimentation, grazing, and water fow have been repeatedly highlighted as important determinants of macroalgal assemblage structure (Schicl \& Foster 1986 Witman \& Dayton 2001). In (urn, an appreciation of the interactive effects of physical and biological processes may assist in the developnent of predictive models about the assembly and maintenance of heterogeneity of subtidal communities (Connell 2005).

Depth directly affects different abiotic properlies, such as light availability. nutrient concentrations, sedimentation, and temperature (Garrabou et al. 2002). For example, an increase in depth is associated with a decrease in light availability and typically in algal grow h. which affect the community dominant (Witman \& Daylon 2001). A considerable small-seale horizontal spatial variability (from contimeters to meters) in the structure and abundance of algal assemblages clearly indicate that other mechanisms are also relevant to influence patterns in algal abundance and assemblage structure on subtidal reefs (Fowier-Walker \& Comnell 2002. Schils \& Coppejans 2003 Terlizzi ct al. 2(0)7). For example. sediment deposition maty disturb, and so alter, algal diversity and abundance at small scales (Schiel \& Foster 1986. Airoldi \& Virgilio 1998), often indirectly facilitating opportunistic filamentous turfs to replace adversely affected canopy-forming. erect, macroalgae (Airoldi

* Corresponding at1hor. E.-mail: f.tuyaato ecu.cdu.au
\& Cinelli 1997, Irving \& Connell 2002), although sediment disturbance may promote diversily through preventing monopolization of space by compctitively superior species (I.ittler et al. 1983b, Airoldi, 2003).

The presence of high sea urchin population densities has been widely advocated as a key mechanism determining the organization and functioning of temperate ref's: Overgrazing by sea urchins may cause the elimination of erect macroalgae, ultimately turning algal beds into "urchin-grazed bartens" dominated by algalcrusts and sessile invertebrates (t.g., Dayton ct al. 1992. Andrew 1993. Andrew \& Underwood 1993, Shears \& Babcock 2003. Graham 2004, I luya et al. 2004bj. The intensity of sea urchin graping, and subsecuently its offects on the organization of benthic assemblages. is, however, considerably heterogeneous through space and time (Benedelti-Cecchi et al. 1998). A range of biolic and abiotic mechanisne can alter sea urchin densities, and so grazing rates. for the former, shifts in the behavior (Sala et al. 1998) and recruitment (Ebert 1983. Balch \& Scheibling 2000) patterns are two of the main studicd mechanisms. whereas for the latter, differences in lurbulence. wave action, substrate rugosity, and heterogeneity are factors routincly advocated to influence the effect of sea urchin grazing over algal assemblages (Lawrence 2001). For example, water turbulence typically decreases with increasing depth (Denny 1988. Roberts et al. 2006), and may therefore increase the susceptibility of erect itgae to sea urchin grazing (Alves et al. 2001, Tuya et al. 2007, Shears et al,, 2008). Similarly, the negative effect of sea urchin gfazing over erect macroalgat can he exacerbated under scenarios of increased sediment loads that facilitate opportunistic filamentous algate through an inhibition of the recruitment of erect macroalgae (Valentine \& Johnson 2005). although the effect of urchins on macroalgae can be 
reduced when high lewels of sedimentation bave adverse cfects on larval and postsettlement survival of seal urchins (Shears el al. 2008 ).

The long-spine black sea urehin. Ditedemat anthlomm (Philippi). is a gregarious cchinoid that oceurs in almose all marine habilats in the shallow subtidal across the warm temperate waters of the easlern N1lantic. lrom Matdeira to the Gulf of Guincal. In this region, this species plays a key role in structuring subtidal rocky reef (Alves et al. 2001. Thya al al. $2004 \mathrm{~b}$. because it is directly involved in the translormation of large reef areas previously conced by ereet algac to barrens. following the classic trophic cascades paradigm (Salat al al. 1998). Indeed. the contribution of other grazers (e.g. herbivorous fishesi to the generation of red balrons is negtigible when compared with the grazing caused by $D$. anthllarm (Tuya at al. 2004il).

Potential interactions between different factors are often ignored in tests of hypotheses aboul the structure of benthic assemblages, although they might clarily a substantial amounl of the spattial variability among whole assemblages. In this study. we experimentally determined the interative effect between the occurrence (absencers. presence) of the long-spinc black sou urchin. D. anthlarm. and differences in depth and sedimentation (ambient is. enhanced) to create patterns in the assemblage structure of macroalgate on castem Atlantic rocky resfs. Specifically. We manipulated sea urchin densities and predicted (I) that removal of sea urchins would differently atlect macroatlgak atsimblage structure between deep and shatlow reef stratit, and that (2) the elfect of seat urchin removal on matroalgate assemblage structure would be altered under different scenarios of sedimentation (enhanced vs. natural): in parlicular. we predicted that erect. bushlike alyde would bo more alfected by urchin grazing than filamentous turts, where sediment loads are heavier.

\section{MATLRIALS AND MFTHODS}

\section{Study Area}

The study was carried out al 3 locations. I $2 \mathrm{~km}$ apart, on the northeast coalst of Gran Canaria (The Canarian Archipelago. 28 $\mathrm{N}$, eastern Allantic Occan). liom March 2907 March 2008 . Each location encompases rocky (basaltic) recfis denuded of vergelation ("urchin-grazed batrens") from approximately 4 $20 \mathrm{~m}$ depth. and are exposed to the prevailing swells and seas from the northwest and northealst. respectively. Ocoanographic variables (i.c. current patterns. sea surlace temperature, exposure 10 wates are typicilly similar from one location to the other (Conzalez Barbuzino 2063). Sea surtace temperalure fluctuates from $1 \mathrm{R}-15^{\circ} \mathrm{C}$ in winter to $2324^{\circ} \mathrm{C}$ in summer. In this areal. the distribution of benthic communities along the bathymetric axis show's a consistent vertical zonation pattern. Within the shallowest zone $(0.3 \mathrm{~m})$. extersive stalndk of algal assemblages principally, bushlike algae (Tuya \& Haroun 2006)-. dominate the community, and long-spine sea urchins only oceur in low densitics $(0-1 \text { individuals } m)^{\circ}$. Intensive grazing by $D$. anthatum produces clar interfaces between these shallow-twater algal slands and deeper areas devoid of vegetation ffrom below $3 \mathrm{~m}$ of depth. long-spine sea ufchin meàn densities typically range from 4-6 individuals. $m^{2}$ [Tuya et ill. $2004 \mathrm{bj})$.

\section{Interactive Effects Butween Sea Lrchin Presence and Dopth: Experimental Dexign}

At ealch location. circular plots (diameter. $2 \mathrm{~m}$ ) were created by either removing all urchins ( $\mathrm{U}$ ) or preserving urchin densitics at matural levels (i.e. untouched controls. - U). Nil plots were set up on horizontal reef surfaces with similar densitics of urchins tranging from 46 individuals $\mathrm{m}^{7}$ ). and devoid of erect vegetation. The center of each experimental plot was marked with a metal stake drilled into the reef and latheled for subsequent identification. Two plots of each treatment ! U and $+U$ ) werc established a1 2 depth strata deep $(16-18 \mathrm{~m})$ versus shallow $(89 \mathrm{~m})$ - within weh location (i.e. 8 cxperimentat plests per location). All plots were created al the beginning of March 2007. and were sisited approximately crery 4 wh to maintain treatments and to quantify thanges in assemblage strueture, until the end of the experiment ( March 2008). Because adult $D$. ansillartam individuals show a clear "homing behavior" (Tuya a al. $2004 \mathrm{c}$ ). colonization of urchin removal plots (- $\mathrm{U}$ ) was mostly restricted to juveniles (personal observation) throughoul the study, which hide in cryptic reef microhabitats such as cracks and crevices (Hernindez 2006). Immigration ot adult $D$. anth/ham into urchin removal plots ( 1$)$, at any time during the 4-uk period, was, in all cases. less than or equal to 2 individuals por plot. and individuals were removed.

\section{Interactive Effects Between Sea Lirchin Presence and Scdimentation: Experimental Design}

The second experiment sats conducted at the same locations using the same methods deseribed for the previous experiment. but was only conducted at a single depth stratum (12-14 m). At cach boation. 2 plots of each urchin treatment $(\mathrm{U}$ and $+\mathrm{U})$ were subjected. every 4 wh, lo an "enlanced" scdimentation tratment by adding sandy $(0.28 \mathrm{~mm}$ mean grain diamster) sediments (40.44 g wet weight per experinental plou as a tine "rain" (Airoldi \& Vircyilio 199s. Connell 2005) uniformly distributed within each plot. The other 4 plots were malintained at "natural]" (j.e. unmanipulaticd) levels of sedinentation. To determine at proxy to the level of sedimentation in the study area, 4 funnel-like sediment traps $\left(63.58 \mathrm{~cm}^{2}\right.$ of upper circular area) were established. $30 \mathrm{~cm}$ above the bottom at 1 lowation. and the mean accumulation rate (nxasured in grams wet weight per sylate meter perday) of itedimemls uas quantified every diay for 4 successive days. Those plots assigned to the "enhaned" sedimentation tratment were subjected to a 3-fold incratise in sodimentation rates $\left(0.67 \mathrm{~g}\right.$ wel weight ${ }^{2}$ day) relative 10 natural sedimentation levels $\left(0.22 \mathrm{~g}\right.$ wet weight m $^{2}$ daly $\left.\mathrm{y}^{\mathrm{i}}\right)$. Such an increase was selected to represent a realistic scenario in the whifts of sediment loads within the study area (Gonzalez Barbuzano 20r)3), which lacks major runoff sources (c.g. . rivers. creeks) Ihroughout the yeat

\section{Sampling}

For both experiments, and at each sampling time (i.e. evers 4 we from March 2007 to March 2008), al scubal diver quanlified in sint the pereent cover of algat in four $50 \times 50$-cm qualdats $\left(0,25 \mathrm{~m}^{2}\right)$ within catch plot. following point-quadrat procedures previously implemented for the study area (a grid of 121 points per quadrat was used in all cases [ [ruyal and Haroun 2006]). Quadrats, lens of centimeters apart, were hapharardly lasid out 
within each plot. This is al rapid. nondestructive technique to assess assembiage struture and dominane of sessile biota (Fow ler-Walker \& Connell 2002. MeClanalhaln et al. 2003). Finil values for each taxon were expressed as percentages. Taxa presented in less than at $4 \%$ cover were omitted. Responses of algie can be identified, without loss of significant information. through taxonomic groups instatad of species (Terlizzi et al. 2003). Macroalnace were thus calegorized into 3 morphological groups. by tiking into account the algal form groups reported in the literature (Steneck \& Dethier 1994. Fowler-Walker \& Comeli 20012. McClanahan el al. 2003: Vaselli et al. 2008), and previously implemented in the stldy area (Tuya and Haroun 2006). Turf algate (hereafter retered to as TA) consist of small cushion-shaped and filamentous species, usually less than $5 \mathrm{~cm}$

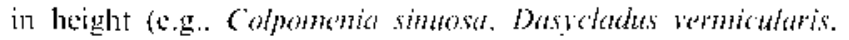
Jamia spp. (Cotumitm spp.). Bushlike algate (hereafter teferred to as BA) are crect. coarsely branched algate (c. g.. Asporagopsis

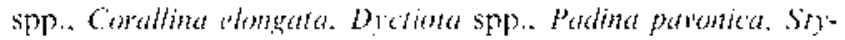

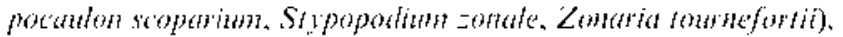
from $1.15 \mathrm{~cm}$ in height, which constitute either large algal cushions or thin sheets. Finally, conalline algate (hereafter referred to as ( A consisted of algat crusis (e. g.. (he genera Lithothamion.

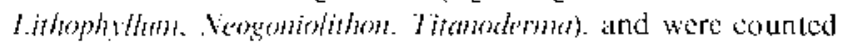
when not overgrowin by other algake.

\section{Statistical Analysis}

For eath exprriment, differences between categories (atnd combinations) of predictive factors were evaluated using multiand univariate analysis of variance (ANOVA). Permutational analysis of varianese (PERMANOVA [Anderson 2001]) was used to partition both multivariate and univariate variability. becaluse this approach allows multivariate testing for interactions. and uses pormutations to calculate $P$ values. The latter was preforable beciluse the dala were from unknown distribulions and werc overdispersed. The test statistic (pseudo $F$ ) is a mulivariate analogue of the unizatiate Fisher's $F$ ratio, and in the univariate context the two are identical when using Euclidein distance ats the dissimilarity measure (Anderson 2001). Because data collected from the same experimental units througl time are often autocorrelated. and so assumptions of analyses may not be met. we analyzed data at the end of the experimental period according 10 is mixed cfiects. 4-factor ANOVA model. incorporating (1) location (randon factor with 3 levels), (2) urchins (fixed factor with 2 levels: U vs. ' I and orthogonal to the previous factor). (3) depth (decp vs. shallow strata) or sedimentation (ambient vs. enhalnced) (fixcd factor with 2 levels. and orthogonal to the previous factors). and (4) plots (randiom factor wilh 2 levels. nested within the 2nd order interaction between location. urchin. and depth or sedimentation). Raw data were square root transformed to down-weight the most abundant taxa, and multivariate the entire macroalgal assemblage) and univariate (percent coverage of $\mathrm{TA}, \mathrm{BA}$. and $\mathrm{CA}$ ) analyses were based on Bray-Curtis dissinilarities and Euclidean distances, respectively. $P$ values were calculated from 4.999 unrestricted permutations of the raw data. When appropriate pairwise a posteriori comparisons were execuled using 4.999 permutations to test for differences among levels of fixed factors. To visualize mullivariate patterns, nonmetric multidimensional scaling ordination wats carried out on the square root transformed data. Differences in variability (dispersion) in assemblage structure between treatments were tested through pairwise comparisons with the PERMIISP routine (Anderson 2004) viat 4.999 permutations of the raw datia. All antyses were performed using the PRIMER 6.0 (PRIMER-E Ltd, UK) statistical package.

\section{RESLLTS}

\section{Effects of Uirchin Removal on Algal Assemhlages Betwren Shallow and Decp Strata}

Differences in algal assemblage structure between urchin removal and untouched (control) plots at the end of the experiment shifted from the shallow to the deep stratum (Titble I. PERMANOVA. Ur $\times$ De, $P<0.05$ ); this interitetive effect was consistent among locations (Table I, PERMA.VOVA, Lo $x$ $1 \mathrm{~s} \times$ De. $P>0.1)$, although the effects of urchins and depth shifted among locations (Table 1. PER.MANOVA, Lo $\times$ Ur and Lo $\times$ De, $P<0.01$ ). In general. the structure of the algat assemblages at the shallow stratum was more variable (i.e. dispersed) relative to those algal assemblages at the deep strata

TABILE 1.

Results of multivariate and univariate ANOVA testing the effects of location (random factor), urehins (fixed factor with 2 levels and orthogonal to the previous factor), depth (fixed factor with 2 levels and orthogonal to the previous factors), and plots (random factor with 2 levels, nested within the $2^{\text {Ind }}$ order interaction between location, urchins, and depth) on the structure of algal assemblages and the percent coverage of eacls algal morphological group at the end of the experinent.

\begin{tabular}{|c|c|c|c|c|c|c|c|c|c|c|c|c|c|}
\hline \multirow[b]{2}{*}{ Source } & \multirow[b]{2}{*}{ df } & \multicolumn{3}{|c|}{ Algal Assemblage } & \multicolumn{3}{|c|}{ Turf Algae } & \multicolumn{3}{|c|}{ Bush Algae } & \multicolumn{3}{|c|}{ Crustose Algac } \\
\hline & & MS & $\mathbf{F}$ & $P$ & MS & $\mathbf{F}$ & $P$ & MS & $\mathrm{F}$ & $P$ & MS & $\mathbf{F}$ & $P$ \\
\hline Lodkcations & 2 & 17.479 & 39.37 & 0.000102 & 0.41 & 2.25 & 0.1475 & 66.21 & 10.11 & 0.0027 & 4.35 & 12.28 & 0.0013 \\
\hline Li (urchins) & ] & 25.678 .3 & 5.77 & $0.046 ?$ & 39.47 & 37.99 & 0.025 .3 & 799.26 & 24.49 & 0.039 & 0.09 & 0.86 & 0.451 .3 \\
\hline De (depth) & 1 & .59 .751 & 4.75 & 0.0762 & 52.01 & 45.95 & 0.0 ? 11 & 1186.76 & 11.87 & 0.0478 & 18.4 & 4.08 & 0.1808 \\
\hline Plot $\left.\left(L_{o}\right) \times U_{r} \times D^{*}\right)$ & 12 & 443.34 & 2.58 & 0.0004 & 0.18 & 3.97 & 0.00001 & 65.521 & 5.60 & 0.0000 & 0.35 & 3.69 & 0.0866 \\
\hline $\mathrm{Lo} \times \mathrm{U}_{\mathrm{T}}$ & 2 & $4.44 \dot{x} .1$ & 10.02 & 0.00002 & 1.0 .3 & 5.71 & 0.0181 & 32.00 & 4.98 & 0.0266 & 0.10 & 0.31 & 0.7413 \\
\hline Lo $\times \mathrm{Dc}$ & 2 & 12.581 & 28.3 .3 & 0.0009 & 1.14 & 6.22 & 0.014 & 95.57 & 14.59 & 0.0006 & 4.52 & 12.78 & 0.0011 \\
\hline $\mathrm{Ur} \times \mathrm{DC}$ & 1 & $5,863.4$ & 11.30 & $0.026 \mathrm{x}$ & 2.09 & 7.94 & 0.1062 & 341.26 & 11.74 & 0.0757 & 1.01 & 1.85 & 0.3072 \\
\hline $\mathrm{I} o \times \mathrm{l}: \mathrm{r} \times \mathrm{De}_{\mathrm{e}}$ & 2 & $518 . x$ & 1.16 & 0.3696 & 0.26 & 1.45 & 0.2723 & 29.07 & 4.44 & 0.0 .361 & 0.54 & 1.55 & 0.2529 \\
\hline Residluitl & 72 & 172.27 & & & 0.04 & & & 1.17 & & & 0.20 & & \\
\hline
\end{tabular}


(Table 2. PERMDJSP, most pairuise comparisons, $P<0.01$ ), which, inded, tended to cluster together in the ordination space (tig. l).

For TA, the direction and magnitude of differences between urchin treatments ( $\mathrm{U}$ \%s. i U) was consistent between depth stratia (Table $1, \mathrm{Ur} \times \mathrm{Dc}$ and $\mathrm{Lo} \times \mathrm{Lr} \times$ De. $P>0.10$. Fig. 2). We detected differences in the percent coverage between urchin Ireatments (-U vs, $-U$ ) and depth strata (Table I, urchin and depth. $P<0.05$. Fig. 2). Those plots where urchins were removed $(-\mathrm{L}$;) contaned 3.1 times more alyal cover than untouched (control) plots (-L), whereas plots at the shailow reef stratum contilined 1 .6 lines more algal cover than the deep reef stratum (Fig. 2). These differences betwen urchin treatments and depth strata, however, differed slightly in magnitude among locations (Table 1 , Lo $\times$ Lr. $1.0 \times 1$ de, $P<0,05$, rig. 2 ).

In the case of $\mathrm{BA}$, differences between urchin tratments varied from the decp to the shallow reef stratum (Tahle . Vr $\times$ De, $P-0.07$. Fig. 2). as a result of a larger malgnitude of response (i.c.. larger percent of coverage) in the shallow relative to the deep stratum (Fig. 2), which even varied among locations (Table 1. Lo $\times$ Lir $\times$ De. $P<0.05$. Fig. 2). We delected differences in the pereent coverage between urchin treatments ( L: vs. II) and depth strata (Table 1, urchin and depth, $P$ < 0.05 , Fig. 2). These plots where urehins were removed $(-$ J) had 3.4 times more cover of al gate than plots where urchins were not eliminated (+U), whereas those plots at the shallow reed st ratum had 5.7 times more cover of algae than the deep reef stratum (IFig. 2). These differences between urchin treatments and depth strata differed in magnitude among locations (Tabic 1 , Lo $X$ Ur. Lo $\times$ Je. $P<0.05$. Fig. 2 ).

Finally, and for CA. location no. I contained a larger percent coverage than the ollere locations at the end of the experiment (Table I, location, $P<0.01$. Fig. 2). particularly at the shallow stratum. which resulted in an interactive effect between these 2 lactors (Table 1, Lo $\times$ De. $P<0.01$. Fig. 2). No other significant effects were detected

\section{Effects of Lirchin Remoral on Algal Assemhlages Between High and Lou Levels of Sedimentation}

The effecl of urchin manjpulations (-U vs. +L) on algai assemb]age structure was irrespective of sedimentation levels at the end of the experiment (Table 3, P'FRMANOVA. Lir $\times$ Se, $P>0.05$ ) (tig. 3), although il varied among locations (lable 3. PER.MANOVA. Lo $\times$ Ur, $P<0.05$ ). Moreover, differences in dispersion in ascmblage structure were not observed among

TABLE 2.

Results of pairwise comparisons of multivariate dispersion between sea urchin treatments (removals [-U] is. untouched controls $[+\mathrm{L}])$ from shallow to deep strata.

\begin{tabular}{|c|c|c|}
\hline Ciroups & $t$ & $P$ \\
\hline - Li shallow versus L shallow & 51.606 & 0.001 \\
\hline - U shallow versus · L deap & 61.981 & 0.001 \\
\hline -l: shallow versus U deepp & 35.019 & 0.000 \\
\hline L shallow versus t L deep & 29.805 & 0.012 \\
\hline -L shaldow versus t deepr & 0.61471 & 0.72 \\
\hline .. L' deen versis - 11 deep & 22.442 & 0.10 \\
\hline
\end{tabular}

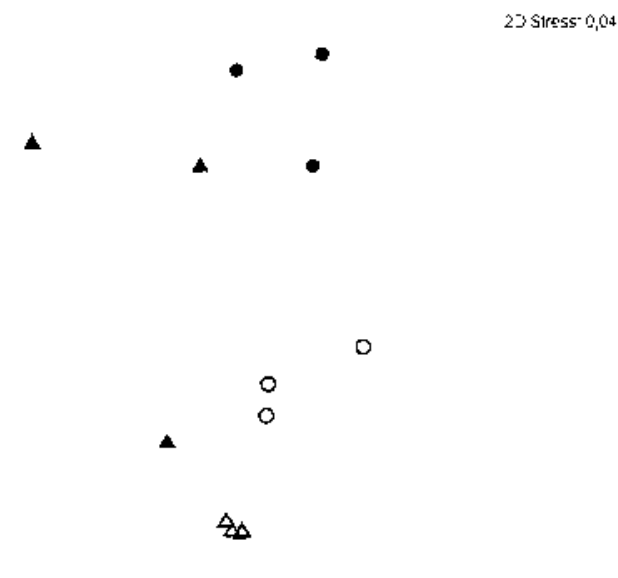

Figure 1. Two-dimensional nonmetric maltidimensional sealingr plot showing centroids of algal assemblages that were subjected to sea urchin removals (circles) or preserved at natural dersities of sta urchins (untouched controls, triangles) at shallow (open symbols) and deep (filled symbols) strata at the end af the experinental period. Replicated plots have been averaged within each treatment for each of the 3 locations.

treatments (all pairwise comparisons. $P>0.05$. PERMDISP. Table 4. except between --U - sediments and $-U+$ sediments).

For both TA and BA, we observed a signilieantly larger cover, at the end of the experiment within those plots where urchins were removed (Table 3 , urchins, $P<0.65,2.1$ times for TA and 2.5 (imes for BA, Fig. 4), irrespective of levels of sedimentation (Table 3. Lir $\times$ Sc, $P>0.05$, Fig. 4). Differences between levels of sedimentation did not cause a significant change in the cover of both algal groups (Table 3. sedimentation, $P>0.05$, lig. 4). Finally. location no. I contained more CA than the other locations at the end of the experiment (Tatble 3. location, $P<0.01$. Fig. 4), which even restited in an interactive eflect with urchin treatments (Table 3 , (I. $\times$ Lo, $P<0.05$, Fig. 4). No other significant effects were detected.

\section{DISCUSSION}

\section{Effects of Lrchin Renowal on Algal Assemblages Betwe't Shallow' and Decp Sriata}

The key role that sea urchins play in determining algal assemblage structure has been experimentally demonstrated throughout temperate latitudes (e.g.. Bayton at al. 1992. Andrew 1993. Benedetti-Cecchi et al. 1998. Alves et al. 2001. Bulleri et al. 2002, Graham 2004). Typically, an increase in the cover of erect algate, including both turf and bushlike algae. within plots where sea urchins were eliminated (or reduced) has been observed, which is consistent with our obscrvations from subtidal rocky reefs at Gran Canaria. Similarly, differences in the composition and structure of sect macroalgae between bathymetric strata have been observed at temperate subtiobal reels (e.g. Gatrabou et al. 2002. Ba1 at a1 and Piazzi 2008, Verges el aI. 2009). More important, our study demonstrated that the magnitude of differences in algal assemblage structure between plots subjected to urchin minipulations (removal vs. untouched controls) shifted from shallow to decp watcrs. These results hightight, therefore, the capacity for plysical condilions (i.c., depth) to interact with biotic processes (i.e., urchin abundance) 

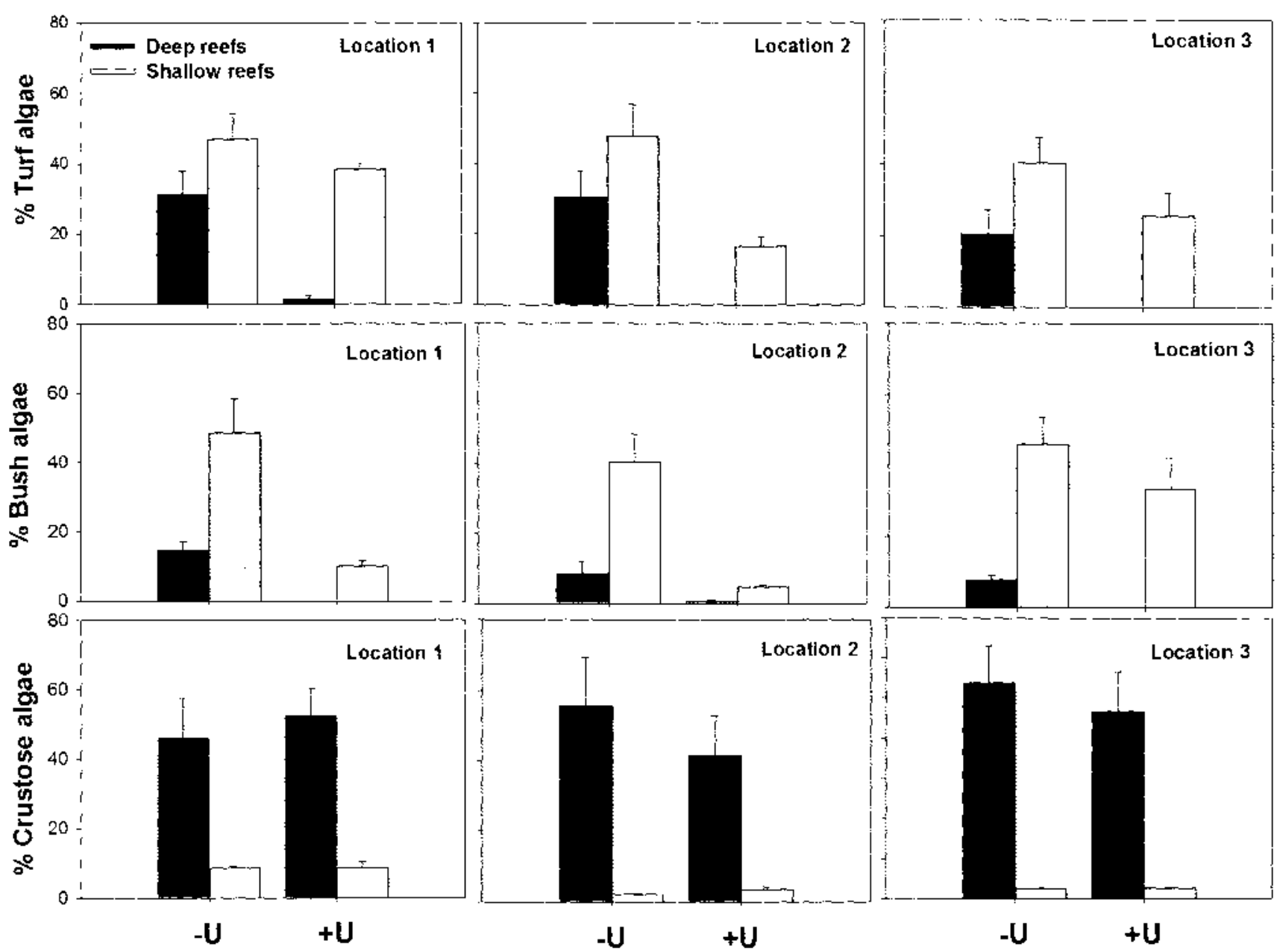

Figure 2. Mean percent coverage of each morphological group subjecled to sea urchin remosal (-I) in preserved at natural densities of sea urchins ( + l) at shalkow (gray bars) and deep (bluck bars) strata at the end of the exprerintental period. Error bars are $\pm S E$. of means $(n=8)$.

to create patterns in the organization of subtidat, benthic asscmblages. Differences in depeh not only maintain differences in the composition and structure of algal assemblages. but can also give rise to divergence during succession when the densitics of major grazers are altered. in this context. bushlike algate increased more in abundance (i.c., cover) in the shallow than deep waters whell trchins were removed: a pattern that was nol observed lor turf algat. Such a result dembristrates the capacity for depth to impose a strong synergistic effect that facilitates the assembly and maintenance of bushlike algate in shallow waters.

Typically, large patches where major grizers are excluded are colonized by a range of algal species. mainly via arrival of propagules from adjacent populations (Airoldi 2000). Diffierences in their atilities to survive and grow subsequently affect patch colonizition. Because an increase in depth is linked with a decrease in light avalability, and then a decline flimitation in algal growth. the resulsts of our experinkent suggest that growth is more light limited for bushy algae relative to turf algac. This perception is in agreement with their different morphologios and ecologies (Stencek \& Dethier 1994. McClanalatan et al. 2003), and could partially explain the comparatively large increase in the cover of bushlike algate where sea archims were removed. from the deep to the shallow stratum. In generat, it filamentous (or a cushion-shaped) morptrology is more efficient than a bushy one to capture photosynthetically active adiation (PAR) light (Littler et al. 1983b; for example, self-shading is more fimited relative to bushlike algae (Littler \& Amold 1980). Moreover, it is also possible that proximity to the souree of propagule donors could explain some of these observations. Becatuse extensive stands of bushlike algat dominate the conmunity within the shallowest zone $(0) 3 \mathrm{~m}$ ) in the study atea (Tuya \& Haroun 2006), these zones could supply propagules to the immediately eldjacent strata (i.c., the shallow stratum in our experiment). because the dispersion of algik propagules generally shows a sharp. exponential decrease seteral meters away from the algal donor (Sablalices 1990. Kendrick \& Watker 1991. Coleman 20033). Obviously, seseral other potential factors (or even combinations) that vary with (iepth (e.g. Wave-intuced turbulence) could atso affect each group differentially. I'urther experimental approaches are necessary to unravel the various proposed mechanisms behind the observed patterns. The lack of response observed for encrusting coralline algae may be explained by the short duration of the experiment. It is likely that hoth lurf and bushlike algae did not have sutficient time to moropolize the entire arailable spuce within plots. which prevented the competitive exclusion of encrusting coralline alyate. In addition. encrusting coralline algate are able to teduce settement of 
TABI.F. 3.

Results of multivariate and univariate ANOVA testing the effects of location (random factor), urchins (fixed factor with 2 levels and orthogonal to the previous factor), sedimentation (fixed factor with 2 levels and orthogonal to the previous factors), and plots (random factor with 2 levels nested within the $2^{\text {nd }}$ order interaction between localions, urchins, and sedimentation) on the structure of algal assemblages and the percent coverage of each algal morphological group at the end of the experiment.

\begin{tabular}{|c|c|c|c|c|c|c|c|c|c|c|c|c|c|}
\hline \multirow[b]{2}{*}{ Source } & \multirow[b]{2}{*}{$d f$} & \multicolumn{3}{|c|}{ Algal Assembiage } & \multicolumn{3}{|c|}{ Turf Algae } & \multicolumn{3}{|c|}{ Bush Algat } & \multicolumn{3}{|c|}{ Crustone Algae } \\
\hline & & $\mathbf{M S}$ & $\mathbf{r}$ & $P$ & MS & $\mathbf{F}$ & $P$ & MS & $\mathbf{F}$ & $P$ & MS & $\mathbf{F}$ & $P$ \\
\hline Lo (lociation) & 2 & 5.414 & $42.7 x$ & 0.0002 & 1.09 & 4.7 .3 & 0.03006 & 6.70 & 18.43 & $0.0000 ?$ & $4 \times 3.34$ & 114.90 & 0.000(\}$)$ \\
\hline Cr (urchins) & 1 & 5.649 .7 & 7.21 & $(1.01310$ & 13.65 & .38 .65 & 0.0249 & 27.3 .3 & 28.82 & 0.03 .30 & 49.54 & 2.27 & (j.27)। \\
\hline So (sedimentaltiot) & 1 & 1.861 .4 & 532 & 0.01924 & 0.05 & 0.14 & 0.7485 & 0.67 & 4.12 & 0.1794 & 12.76 & 1.08 & 0.4075 \\
\hline Plol $\left(\mathrm{L} 0 \times \mathrm{Li} \times \mathrm{Se}^{2}\right)$ & 12 & 126.5 & 0.81 & 0.7261 & 0.23 & 4.59 & 0.0.000 & 0.36 & 2.51 & 0.0081 & 403 & 1.16 & 0.3265 \\
\hline $\operatorname{Lo} \times U_{0}$ & 2 & $7 \times 4.1$ & 6.19 & 0.00002 & 0.75 & 1.53 & 0.2564 & 0.94 & 2.60 & 0.1150 & 21.57 & 54,3 & 0.021 \\
\hline $1.0 \times \mathrm{SL}$ & 2 & 349.7 & 2.76 & 0.0033 & 0.38 & 1.68 & 0.2275 & 0.16 & 0.45 & 0.6481 & 11.79 & 2.93 & 9093 \\
\hline $\mathrm{S} r \times \mathrm{Se}$ & ] & 1.303 .4 & 1.63 & 0.2876 & 1.24 & 1.47 & 0.3489 & 4.35 & 303 & 0.2237 & 0.84 & 0.05 & 0.8487 \\
\hline Lo $\times \mathrm{Cr} \times \mathrm{Se}$ & 2 & 800.93 & 6.32 & 0.0004 & 0.88 & 3.81 & 0.0524 & 1.13 & 3.13 & 0.0982 & 14.00 & 3.47 & 0.1055 \\
\hline Residdual & 72 & $1,56.7$ & & & 0.05 & & & 0.14 & & & 3.46 & & \\
\hline
\end{tabular}

potential competitors. suggesting that they do not rely on grasing by herbivorses (e.g. stat urchins) to prevent at complete swamping by erect algatl species iBulleri et a1. 200)?.

Finally, results from this experiment indicated that the structure of the alyal assemblages at the shallow stratum was considerably more valuable compared with algal assembliges at the decp strallum. These tesults support the notion that shallow environments ate typically more variable. and more extreme. than deeper oncs (Garrabou et al. 2002). Indeed. shallow habitats are notoriously affected by fluctuations in a suite of environmental factors, such as scitwater temperature. turbulence and exposure to hydrodynamie forces, salinity, light, and so forth. through annual cycles (Denny 1988). As a result. substantial fuctuations in such a ritnge of lactors induce at high degree of environmental, and thus ecological. heterogencity.

\section{Lffects of Lifchis Removal on Algal Assimblages Beture's} Itigh and Low Lercts of Sedimentation

An increase in the cover of both turf and bushlike algae was detected, agalin. where sea urchins were elminaled. Howcver. pulterns in the strueture of these assemblages were irrespective of sedimentation levels. I ilamentous algae may tolerati heavy sediment aceumulations (Airoldi \& Virgilio 1998. Airoldi 2003. Connell 2005). Similarly. enerusting coralline algak hate been also experimentally obsersed to be unalfected by large sedimentation (Kendrick 1941, Vasclli et al. 2008). although negative effects of sediment are possible for some laxa (Airoldi

TABIE 4.

Results of pairwise comparisons of multivariate dispersion between sea urchin treatments (removals $[-\mathrm{L}$ is. untouched controls $[+\mathrm{L} \mid)$ and levels of sedimentation.

\begin{tabular}{|c|c|c|}
\hline Giroups & $t$ & $P$ \\
\hline -L: stodiments is -L; hediments & $5 \times .242$ & 0.058 \\
\hline - l: sediments s.5. +l； sediments & 14.394 & $0.07 \%$ \\
\hline -U -sedimetsts ss. $\mathrm{C}+$ +cotlimemo & 16.404 & 0.067 \\
\hline 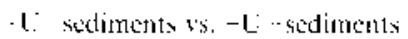 & 60.828 & 0.003 \\
\hline - L. sediments is. L-sediments & 39.072 & 0.088 \\
\hline -li +scdimellls vs. Q: I sediments & $0.5(0)$ & $0.4: 8$ \\
\hline
\end{tabular}

2003). For bushlike algac, the lack of response to a change in the level of sodimentation is somehow unexpected. particulaty when coupled with a change in the densities of mijor grazers (Vatentine \& Johnson 2005). Several reasons can explain this outcome. First, it is possible that the dose added was insulficient to detect a significant thange in these algal ansemblitges; it is also possible that the duration of the experimental period, and even the frequency of sediment additions, were not sufficient 10 detect a perceptible change in their matroscopic cover. Tho duration and intensity of sediment treatments greatly alfeet the outcome of these experionents (Airoldi \& Cinelli 1997. Airotdi 2003. Vaselli et al. 2008). For example, the frequency of sediment additions might hase been considerably long: it is possible that sediments were swept atwaty by swells between any 2 consccutive additions. Sccond, it is also possible that hushlike algae in the study area may tolcate sedimentation more efficiently than previously suspected. Third, we cannot rule vut the possibility that the experiment was carried out at at depth too deep for BA. At the moment, it is difficult to estimate the relative inporlance of these explanations. For example. despite

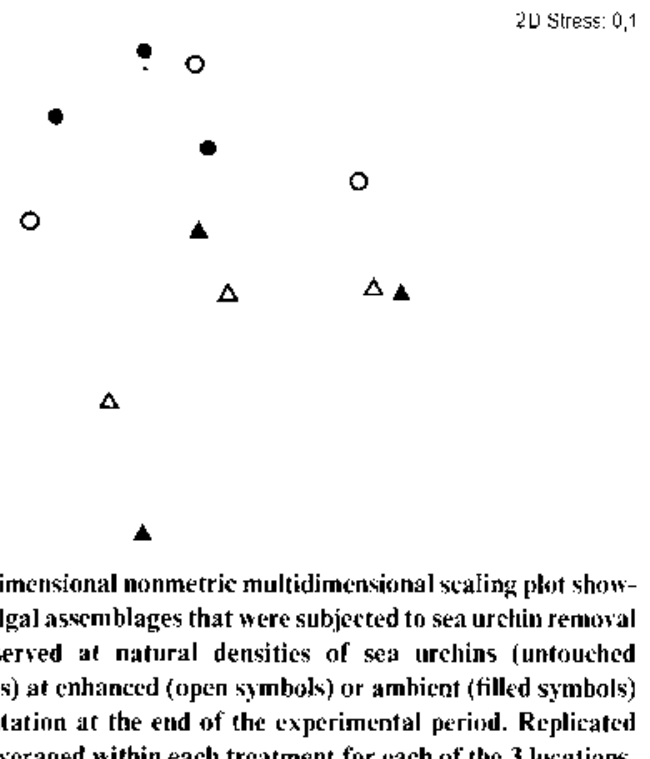

A $+U \operatorname{sed}$

- -U.Sed

$\Delta+U+$ Sed O $-U+\operatorname{Sed}$

Figure 3. Two-dimensional nonmetric multidimensional staling plot showing centroids of algal as:cmblages that were subjected to sea urchin renoval (circles) or preserved at natural densities of sea urchins (untouched controls. I riangles) at chhanced (open symbols) or ambicnt (filled symbols) levels of sedimentation at the end of the experimental period. Replicated plots have been averaged within each treatment for each of the 3 lecalions. 

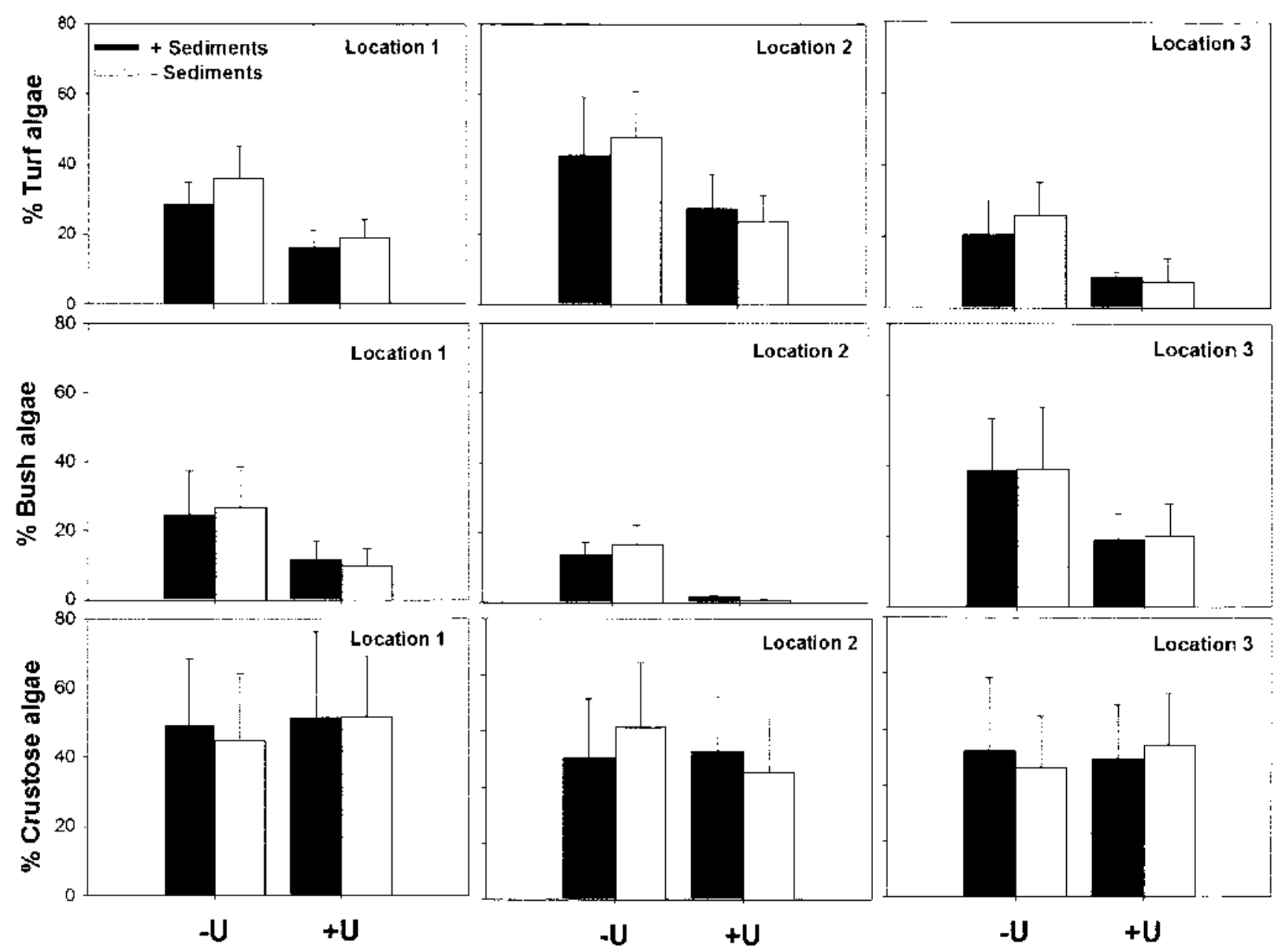

Figure 4. Mlean perent cowerage of each motphological group suljected to seal urchin removal (-l) or preseryed at natural densitiex of sea urchins (+l!) at enhanced (+iediments) or ambient levels ( sediments) of sedimentation at the end of the experimental period. lirror bars are \pm SF. of means $(n=8)$.

the face that most studies dealing with the effects of sedimentation on macralgae have experimentally added doses I-2 orders of magnitude larger than ours (Airoldi \& Virgilio 1998 , Connell 2005), a slight reduction in the amount of sedinents sinking over algal isscmblages can affect the diversity and dominance of algate particularly with regard to colonization of patches of bare rock (Airoldi \& Cinelli 1997), similar to those plots where vea urchins were removed. Because species-specilic responses to sediment-induced disturbances and the local charateristics of the regine of sedimentation considerably atfect the response (Airoldi 2003). it is obvious that further experimental approalches are necessary to address the interac- tive potential of sedimentation with biotic mechanisms ti.e. grazing. competition) shaping the orgatnization of subtidal benthic assemblages in the study area.

\section{ACKNOWLEDGMENTS}

The atuthors thank 1. Bertocci. M. S. Thomsen. M. A. Vanderklift. and $\mathrm{I}$. Wernberg for providing positive criticism and discussion in previous dratts of this manuscript. Financial support for this work tals provided by the Cabildo de Gran Canatria through a postgraduate research fellow 10 L. O.- B.

\section{IITERATIRE CITED}

Airolki, 1. 2000. Responses of algae with different life historjes to temporal and spatial ariahility of disturbance in subtidal reefs. War Liol. Prog. Sor. 195: $\mathrm{x}-\mathrm{-1})$ ?

Airoldi. L. 2003. The eflects of sedimentation on rocky costst atsemblasges. Oceuntugr. Wor. Bith. Annut Rer. 41:161--236.

Airoldi. L. \& F. (inclli. b997. leftects of tedimentation on subtidal macroalgal assemblages: an experintental study from a Mediterra-

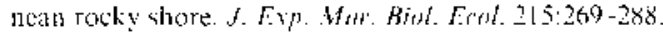

Airoldi, L. \& M. Virgilio. 1998. Responses of turf-forming aleade (1) spatial variations in the deposition of sediments. 1far. Erol. Prese $S+165: 271282$

Alves. F. M. A.. L. M. Chichato. [.. Serrio \& A. D. Abreu. 2001. Alüal] cover and seat-urchin spatial distribution an Madeira Island \& $\mathrm{NE}$ Atlantici. Sor. Her. 65:383 39 ?

Anderson. M. .. 2001. A new method for non-patratmel ric nuitivisiate inalysis of vitriatuce in ecology. Atrsfral Eorl. 26:32 46. 
Andersom. M. J. 2OHt. PERMDISP': a I OR I RAN computer program lor permutational illalysis al mathisariate dispersions (for any 1wo-dictor ANOVA designt using permulition tests. Auckliand. Neu Zcalatnd: Departenent of Statistics. Lluivervity of Auckland. 1] $\mathrm{pp}$.

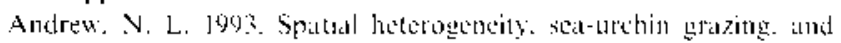
habitall structure on reefs in lemperate Austrilta. Ecolog! 74:292 302 ?

Andrew. N. L. \& A. J. L'ndernond. 1493. Density-dependent foratging

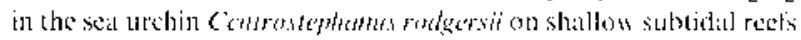

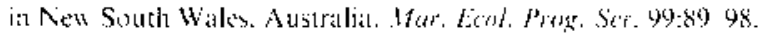

Ballitil. D. \& 1... Piarri. 2008. Pilterms of diverujly jn rocky subtidat

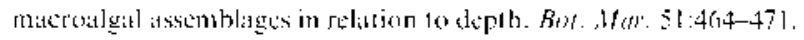

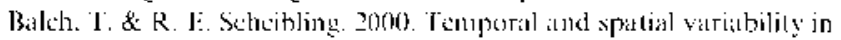
sutlement and recruitment of echifoderms in kelp heds ant birrens

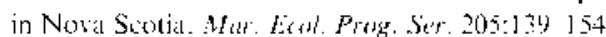

Benedetti-Cexedui. L., F. Bulleri \& F'. Cinelli. 199k. Density dependest loritging of suit urchins in shallow subtidid reets on the west

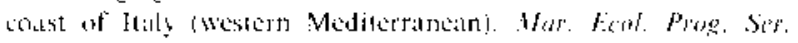
$163: 20: 211$.

Bulieri. F.. I. Bertoce: \& F. Micheli. 2002. Interplay of enerusting toralline algate and wat urchins in mointaining alternative habbitats

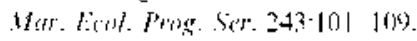

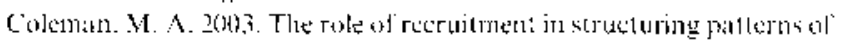

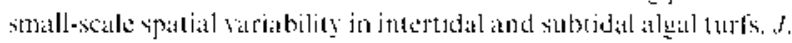
Exp. Hetr. Biel. Lcol $291: 13[-145$.

Commell, S. D. 2006, Assembly and milintenance of subtidal habitat heterogencity: synergistic eftects of light penetration and sedimen-

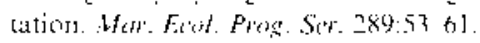

Dilyton. P. K. M. J. Tcencr. P. E. Paltnell \& P. B. Fdwitrds. 1992. [emporal and spatial patterns of disturhance and recovery in a kelp

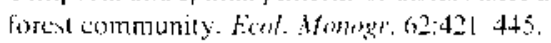

Demot. M. W. 1988. Biotogy and the mechatuisms of ware-swept ansironment. New York: Prinketon linisersity Press. 339 pp.

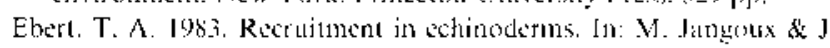
Liltrence, editors. Lehinoderm studies. Rotterdam: Bathenta. PP. 160203.

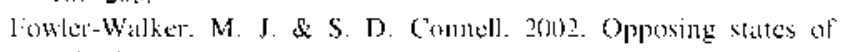

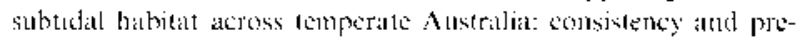

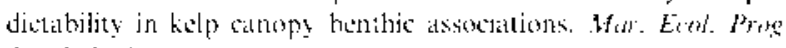
Ser. 240:49) 56.

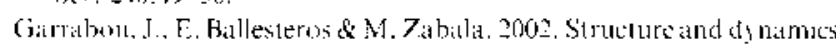
of Xorth-western Mediterrandétn rocky benthic comonumilies along

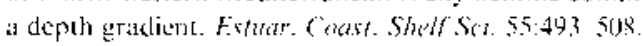

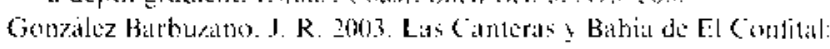
libro hlancer. I.ats Patmas de Gran Canaria: Cabiddo de Gran Canaria. Consejeria de Ohras priblicas a Infraestructeras. $617 \mathrm{pr}$.

Ciraham, M. H. 2004. Edfects of loual detoreslation of the diversity and

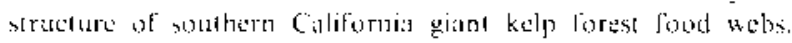

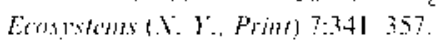

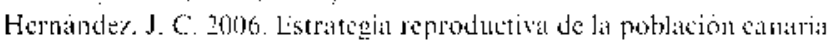

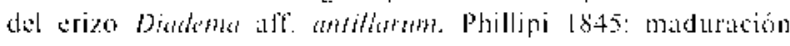
gonadial, itsentamicunto latratrib y reclutamiento. PhD dissortation. Loiversidad de I.a I.igutıa. $242 \mathrm{pp}$.

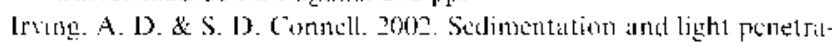
tion interat co maintain heterogencity of subtidal thabitats: al agal us. invercebrate dominated assemblines. Har. Eo ol. Prog. Sor. 245:8.7 91.

Kendrick. G. A. 1991. Recruitment of enrilline cretsts and titamentous

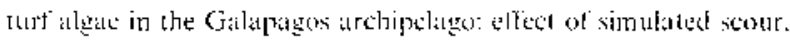
croviten and aceretion. J. Exp. Wor. Biel. Erol. 147:47 6.3.

Kendrict. G. A. \& D. I. Walker. [9y]. Lispersal distatnees for

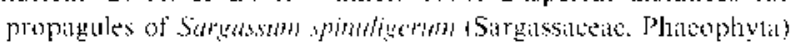
measured diretly by vital stilining and Verturi section sampling. .Hor. Evol. Prog. Sor. 79:13.3 1.38

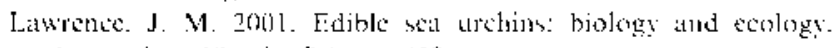
Amsterdans: Ejseriter Stietret. $432 \mathrm{pp}$. 1.iteder. M. M. \& K. E. Arneld. 1986. Soureses of vamiability in macro. alsal primary productivity: sitmpling and interpretive problems. Aqutat. Bis. 3:141 1.56.

Litter. M. M. D. S. Litles \& P. R. Titylor. 1983at. Livolutionary strategics in at tropical harrice reel ystem: functional torm groups of

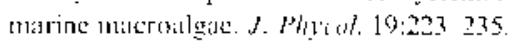

Littler, M. M.. D. R. Warty \& D. S. J.ilter. 1983h. Effects ol recurrent

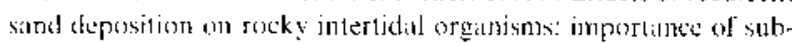
strilte lecterogeneity in a fluctuating enviromment. Her. Leot. Prog. Sir. 11:129-13\%.

1.uning, K. 1990. Seaweds: their emironnunt, hisgeography. and ecophysiology. New York: Wilcy $572 \mathrm{pp}$.

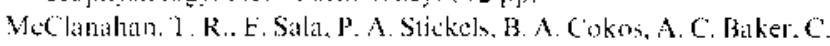
J. Starger \& S. H. Jontis. 2003. Interraction belween nutricnts and herbivery in controlling ilgitl conmunitics atrd coral condition on Glover's Reel. Belize. Whar. Eeol. Progr. S'r. 261:135 147.

Roberts. D. F., S. P. Cumnins. A. R. Davis \& M. G. Chapmatn. 200)t. Struture and dinamics of sponge-dominated assemblages on exposed and sheltered lemperate reds. Hats. Erot. Proger. Sor. $321: 1930$

Sallat. L.. C. I. Boudouresulue \& . M. I.. Harmelin-Vivien. J998. IFishingt. trophic cascides, atud the strusture of algat asscmblages eviluatoris of an old bul antested paradigm. Oiks, 83:425 4.39.

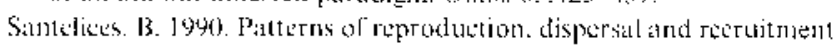

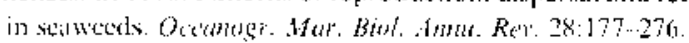

Schiel. D. R. \& M. S. Foster, 1986. I he structure of subtictal algat

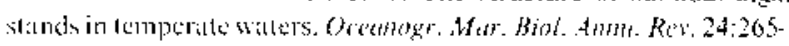
307 .

Schils, T. \& F. Coppejians. 2003. Spatial valriatiom in solvidat plant communities around the Socotris Archipelago and their biogeo.

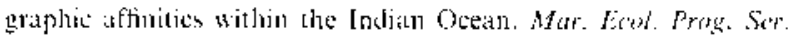
251:103 114.

Shears. N. T.\& R. C. Baboock. 2003. Continuing tropluc cascade clfects after 25 yedrs ol nol-1ake marine reserve protection. Wor. Fiof. Prog. Sir. 246:1-16

Shears, V. T., R. C. Babonck \& A. K. Salomon. 2008 . Contextdependent affects of fishing: varjation in trophic cilscides across snvironmentat gradients. Eicol appl. 18:186il 1873.

Steneck. R. S. \& M. N. Dethier. 1994. A riunctional group approach to the steucture of algal-dominated communitics. Oikes $69: 476$ 498.

Terlizzj. A. S. Bcylacy ua, S. Fuschet1i \& I. Bocro. 2003. Taxonomic sutficioncy and the increasing insufficiency of taxomomic expertise.

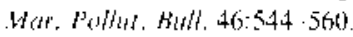

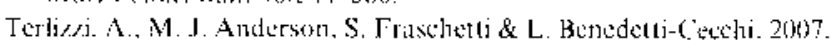
Scialer of spatial variation in Mediterranean subjodal sessile assembletges at different depths. Hur. Erof. Prog. Sor. 332:25 39.

Tuya. F.. A. Boyra. P. Sanchez-Jerez. R. I. Haroun \& C. Barbera. 2004il. Can orse species determine the atructure of a rocky benthic community on a temperate rocky recel: the sase of the lotsy-spined ster

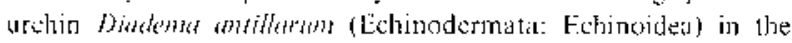

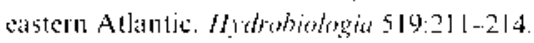

Tuyid. F., A. Boyrt. P. Sinchez-Jerez. R. J. Hatroun \& C. Barterit. 2004b. Relattionships betweet rock y-reef fish assembliges. the sea

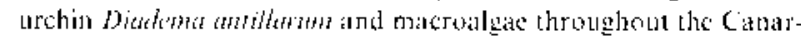

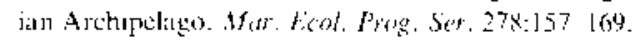

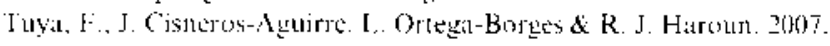
Bathymetric segregittion of sea urchins on refes of the Cantritum

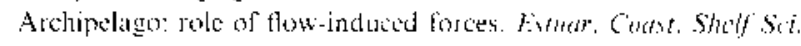
$73: 4 \times 1-4: 8 \times$.

Tuy;. F. \& R. 3. Harroun. 2006. Spattal jatlerms and response to witve exposurte of photophitic aldet assembiages across the Canarian

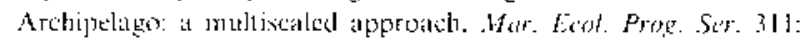
$15.2 \times$

Tuya. F., I. A. Martio \& A. I uque. 2004c. Partersk of nocturnal moxement of the sea urchin Diestema antillaram (Philippit in Gran 


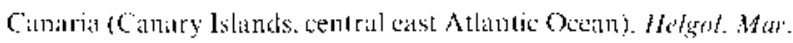
Re... $58: 2631$

Valentine. J. \& C. R. Johnson. 2005. Persistence of sea urelin (Helio-

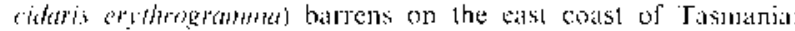
inhibition of macroalgal recovery in the absence of high densities of seit urchins. But. Mar. 48:106 115

Vaselli, S. I. Bertocei. L. Maggii \& L. Benederti-Cecelu. 2008. Hfficts of mean intensity and temperal variance of sediment scouring

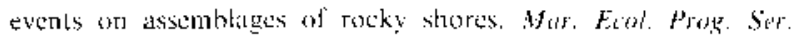
$364: 57-66$

Verges, A. T. Alcoverro \& E. Ballesteros. 20019. Role of lish herbivery

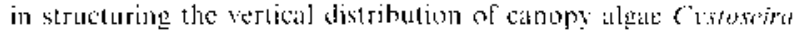
spp in the Medicertanean Sa. Mar. Evol. Prog. Ser. 375:1 I].

Witmatn. J. D. \& P. Dayton. Z001. Roxky subtidial communitiss in: M. D. Bertness, S. D. Gaines \& M. E. Hay. editors. Marine communily ocology. New York: Sinaluer Associates. pp. 339-366. 